Operations during pregnancy should only be done when nccessary, lest abortion ensue, but by steadying the mus. cular and nerrous systems by anaesthesia, even such operations as myomectomy and ovariotomy can be safely performed. Abortion follows 50 per cent. of myomectomies, but rarely follows ovariotomy. Operations for appendicitis complicating early pregnancy do not usually cause abortion, but in the later months premature labour usually results.

\section{FETAL CACSES.}

A. Deivelopyental Cacses of Fetal Death

A very large number of deaths occur during the first few days or weeks after the ovum is fertilized. The human embryo is then merely a mass of cells gradually being placed in defined groups, and undergoing specific changes in character. A faulty grouping oi position of these embryonic cells leads to serious subsequent deformity, or if the attachments to the mother be at fault, to failure in nutrition and early death of the fetus. I have already alluded to developmental defects as a result of industrial occupation during gestation. Many early abortions appear to be due to haemorrhages from the early chorio-decidual-spaces, leading to diffuse clots, which, together with the early ovum, are expelled at the date of the next period without any attempt at the formation of an organized blood-mole, which would be found in the second or third month. I do not.allude to developmental errors in the placenta or cord, the presence of which could not be detected before birtl.

\section{B. Pathological Fetal Conditions.}

Hydatidiformi Disease of the Chorion.-If the uterus is enlarged above its normal dimensions at the supposed date, and fibromyomata are absent, and especially if palpation be unsatisfactory, and there be a "red-currant juice" discharge, this disease may be suspected. Examination may reveal a mass bulging through the dilating cervix. It is possible that a healthy twin may also be present in utero, but this is so rare, and the risk of a subsequent chorion-epithelioma is so real; that the nterus should be emptied; the ovum affected practically never has a living fetus in its centre.

Blood moles and fleshy moles produce somewhat similar symptoms, such as metrorrhagia, but the uterus is usually below its normal size at the presumed date of pregnancy. $O$ wing to interference with the blood supply of the embryo it is always dead.

Hydramnios. - This condition is associated with fetal malformations in nearly 50 per cent. of cases, and the fetus, if otherwise normal, is often feebly constituted and dies within the year. If, therefore, there is serious abclominal distension and resulting dyspnoea, the labour should be ended by puncturing the mombranes.

Fetal Toxaemias. - It is almost certain that some of the toxaemias arise as a result of altered metabolism in the fetal placenta, especially in the cells of the syncytium or of Langlians's layer, and perhaps even in the fetus itself, but no certain proof of this is yet forthcoming. We can only estimate their gravity by their effect upon the mother, and in some cases by the altered heart-beat or intrauterine cleath of the fetus.

\section{Mechanical Fetal Causes.}

Malpositions of the Fetus.-The position of the fetus in utero should always be determined by abdominal palpation or by bimanual examination. It is quite easy, if the child's head be at the fundus or is laterally placed, to encourage it to descend gradually towards the pelvis. After it is pushed down to the level of the navel, its own relative weight in the last month of pregnancy will cause it to engage at the brim. To do this the patient should be seen every two or three weelss after the sixth month.

l'etal Malformations. - Fetus hydroceplialus, anen. cephalus, acephalus, acardiacus, amoiphus, and many other types, lead to many fetal deaths, but. with the exception of the first type, they can rarely be diagnosed during gestation, and treatment is, of course, ineffectual.

Rebatively Large Children.-These are occasionally encountered, especially when the father is a big bony man with a bractrycephatic head and the woman is small and the peltis barely normal. A listory of dystocia or fetal ieath during a previous parturition may lead to the con. dition being suspected and discovered. In stich càsēs a timely induction of labour at the thirty-eighth week malies all the difference to both mother and child.

REFTRENCEs.

1 Report of Conference on Infantile Mortality, 1913, p. 237.2 Ibid. p. 362. Priestley, Pathology of Intranterine Death, British-Mwicar. JOURNAL, March 26th, 1887, p. 661. 4 Williams, Obstetrics, 1912, p. 627. Malins, Antenatal Waste of Iife in Nature and Civilization, Journ: Tausst. and Gymaec. of the British . Fmpire, 1903, iii, 307-319. 7 Clark, Report of Conferen Treatment of Abortion. St. Lounis. Societies," p. 106. "8 Ibid., 1. 423. 9 Journ. of Obstct." and Gynaec. of the British Empire, vol, xix, 1911, p. 48 . 10 Report of Conference on Infantile Mortality, 1. 29. 11 McDonagh, Salvarsan in Syphilis, p. 129 see also BritisH MEDICAL JournaL, 1912, ii, p, 1731. 12 Whitehouse Proc. Roy. Soc. Med.. Obstet. Section, vol. vii. 1914. p 127. ${ }^{13}$ Knöpe 14 Marshall, Brit. Joirn of Children's Diseases, vol. ix, ig12, p. 6 . 15 Sir A Wright. Report of Children's Diseases, vol. ix, 1912, p. 6. Labourers in Africa, Fimes. January 2 nd, $1914, \mathrm{p}, 5.16 \mathrm{~W}$. W Villiams Amer. Journ. Med. Sci. January, 1909. 17 Frank, (1uoted by Priestley BRITIAH MEDical JouRnal, 1887, vol. i, 1) 663 . I8 Swayne, Clinical Significance of Acidosis in Pregnancy, Proc. Roy. Soc: Med.,Ol, Olstet.
Section, vol. v, 1912, p. 315. 19 Williamson, Lancet, May 17th, igl3.

\section{A METHOD OF PRODUCING RAPID AND FATAL, INTOXICATION WITH BACTERIAT PRODUCTS}

NITII SPECIAL REFERENCE TO TIIE CIIOLER.I VIBRIO.
W. J. PENFOLD,
BX
Lister institcte.
AND
H. VIOLLE,
PASTEU INSTITCTy.
(From the Bacteriological Laboratory of the Lister Institute.)"

IT has been shown by Hort and Penfold (1912) that sub. lethal doses of $B$. typhosus culture become lethal if injected in a large quantity of distilled water. They further showed that if the water be injected first into one vein, and the suoblethal dose of culture subsequently into another vein, death resulted.

We bring forward evidence in this paper to show

1. That this same augmenting effect of distilled water is obtained with cultures of $V$. cholerce and many other organisms, and that it is not due to the original brotl employed as the culture medium.

2. That it is obtained with cholera toxin or filtrate, and does not require the actual presence of organisms.

3. That in the case of $V$. cholerae death is frequently immediate, this immediate death suggesting analogies with the acutest anaphylactic intoxication.

4. That if the toxin be injected first and the distilled water two hours afterwards, death may result inmediateiy.

5. T'hat certain toxic substances do not become more toxic on administration in large quantities of distilled water.

6. That lysis of the blood plays a part in the production of these effects.

The rabbit was the experimental animal used. We employed, when possible, animals between 1.8 and 2.2 kilograms. Animals of other weights were uscd, however, but any conclusion in the paper" depending on animals of weights diverging from this standard will be supported by protocols giving the actual wéights. The intravenous method of injection was used unless otherwise stated.

Controls.

The following controls were made, namely: The effect of the intravenous injection of one-thirtieth of the body weight of distilled water, the effect of distilled water with added broth or peptone, and the effect of pure cholera culture.

Contror. I.-Effiect of the Injection of One-thirtieth of the Body Weight of Irater'Intraìcnousliy.

\begin{tabular}{|c|c|c|c|}
\hline & $\begin{array}{l}\text { Weight of } \\
\text { Rabbit in } \\
\text { Kilos. }\end{array}$ & $\begin{array}{l}\text { Quantity of Wate } \\
\text { Injected } \\
\text { Intra venously. }\end{array}$ & Result. \\
\hline 1 & 2.13 & $71 \mathrm{c.cm}$. & Quite well 14 days later. \\
\hline 2 & 2.09 & 70, & Remained quite well. \\
\hline 3 & 2.14 & $71 \quad$ & $\begin{array}{l}\text { Quite well next day, and there- } \\
\text { fore used for a further in- } \\
\text { jection. }\end{array}$ \\
\hline
\end{tabular}

The yoater used throughout was distilled twice. It was used imnediately after the second distillation.

Received for publication February 5 th, 1914. 


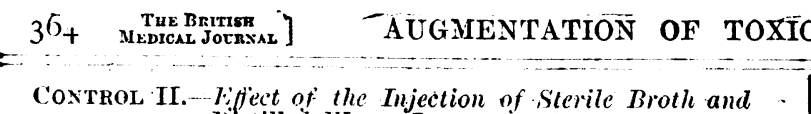

CONTROL II. - Fifect of the Injection of Sterile Broth and
Mistilled Water Intravenously.

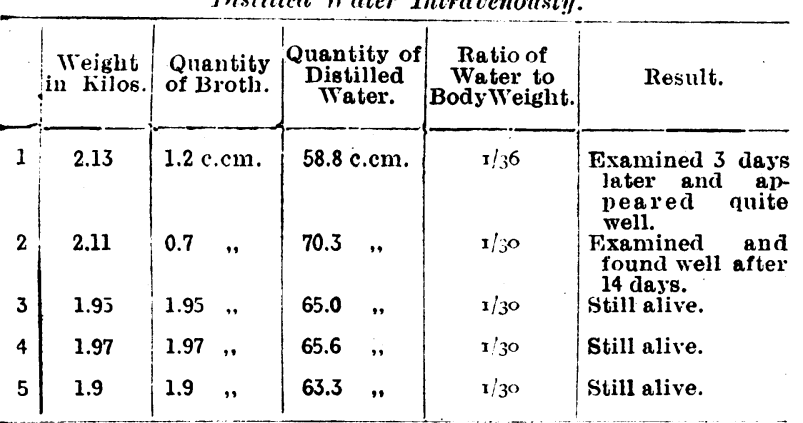

Ordinary broth was made faintly alkaline to litmus and then $10 \mathrm{c.cm}$. of normal soda per litie were added. 'This was the same broth as we used for our cholera cultures.

\section{Experiment I.}

The augmentation of toxic action by distilleã water as obtained in the case of cholera toxin is illustrated by the following experiment:

A four day cholera broth was filtered through a Berliefeld filter, and a series of rabbits were injected with the neat toxin, while another series were injected with the same toxin administered in $\frac{1}{30}$ of the body weight of freshly distilled water.

The results are set forth in the following tables:

Series $I$.

\begin{tabular}{|c|c|c|c|c|c|c|}
\hline \multicolumn{3}{|c|}{$\begin{array}{l}\text { Weight of Animal } \\
\text { in Kilos. }\end{array}$} & \multicolumn{3}{|c|}{$\begin{array}{c}\text { Quantity of Toxin } \\
\text { Per Kilo. }\end{array}$} & Result. \\
\hline \multicolumn{3}{|c|}{1.62} & \multicolumn{3}{|c|}{7.5 c.cm. } & $-*$ \\
\hline \multicolumn{3}{|c|}{1.62} & \multicolumn{3}{|c|}{$5.0 \quad "$} & +1 after $1 \mathrm{hr} .40$ mins. \\
\hline \multicolumn{3}{|c|}{2.27} & \multicolumn{3}{|c|}{$4.0 \quad "$} & + after 2 hrs. 30 mins \\
\hline \multicolumn{3}{|c|}{1.84} & \multicolumn{3}{|c|}{$4.0 \quad$, } & - \\
\hline \multicolumn{3}{|c|}{2.1} & \multicolumn{3}{|c|}{$3.0 "$} & + after one day. \\
\hline \multicolumn{3}{|c|}{1.57} & \multicolumn{3}{|c|}{$3.0 \quad}$, & - \\
\hline \multicolumn{3}{|c|}{1.58} & \multicolumn{3}{|c|}{$3.0 \quad}$, & - \\
\hline \multicolumn{3}{|c|}{1.65} & \multicolumn{3}{|c|}{$3.0 \quad "$} & - \\
\hline \multicolumn{3}{|c|}{1.60} & \multicolumn{3}{|c|}{$2.0 \quad "$} & - \\
\hline \multicolumn{3}{|c|}{1.75} & \multicolumn{3}{|c|}{$2.0 \quad "$} & - \\
\hline \multicolumn{3}{|c|}{1.50} & \multicolumn{3}{|c|}{$2.0 \quad "$} & - \\
\hline \multicolumn{7}{|c|}{$\begin{array}{l}\text { All these were injected with the toxin only. } \\
\text {; The negative sign denotes surviral. } \\
\text { + The positive sign indicates death. }\end{array}$} \\
\hline & & : & \multicolumn{3}{|c|}{ Series $I I$. } & \\
\hline $\begin{array}{l}\text { Weight } \\
\text { in Kilos. }\end{array}$ & \multicolumn{2}{|c|}{$\underset{\text { per Kilo. }}{\operatorname{Toxin}}$} & \multicolumn{2}{|c|}{ Water. } & & Result. \\
\hline 1.82 & \multicolumn{2}{|c|}{$0.5 \mathrm{c.cm}$} & \multicolumn{2}{|c|}{$\begin{array}{l}\text { r/3o of body } \\
\text { weight }\end{array}$} & $+\mathrm{im}$ & ediately. \\
\hline 1.70 & 0.5 & $\because$ & ", & " & + aft & 40 minutes. \\
\hline 2.22 & 0.5 & " & $"$ & " & + aft & 48 minutes. \\
\hline 2.22 & 0.5 & " & $"$ & $n$ & + aft & 50 minutes. \\
\hline 2.52 & 0.5 & ", & $"$ & $"$ & + aft & 54 minutes. \\
\hline 1.71 . & 0.5 & , & ." & . & + aft & 1 hour 2 minutes. \\
\hline 2.25 & 0.5 & $"$ & , & " & + aft & 1 hour 17 minutes. \\
\hline 1.73 & 0.5 & " & ", & " & + aft & 2 hours. \\
\hline 1.84 & 0.5 & " & , & 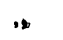 & + nex & day. \\
\hline 1.76 & 0.1 & $\because$ & " & 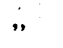 & $+\mathrm{im}$ & ediately. \\
\hline 2.10 & 0.1 & ", & $"$ &. & + aft & 1 hour 30 minutes. \\
\hline 1.71 & 0.1 & $"$ & " & $"$ & $-)^{B}$ & $\begin{array}{l}\text { h very ill at the time, } \\
\text { at recovered, and were }\end{array}$ \\
\hline 2.14 & 0.1 & , & $"$ & $"$ & -5 & $\begin{array}{l}\text { aite well one week } \\
\text { ter. }\end{array}$ \\
\hline 1.73 & 0.01 & , & " & ", & + aft & 1 hour 5 minutes. \\
\hline 1.95 & 0.01 & , & " & $"$ & + aft & 2 hours 10 minutes. \\
\hline 1.95 & 0.001 & & • & " & - & - \\
\hline 1.95 & 0.001 & & " & $"$ & - & \\
\hline
\end{tabular}

Strain $\mathbf{P}$ was used thoughout all our experiments on cholera; it was isolated by Pottevin in Constantinople in 1911, and was used by Pottevin and Violle (1913) in their work on the experimental production of cholera in the lower apes.

Contror III.-To Illustrate the Effect of the Intrarenous Injection of 24-Hour Cultures of V. cholerae in Broth.

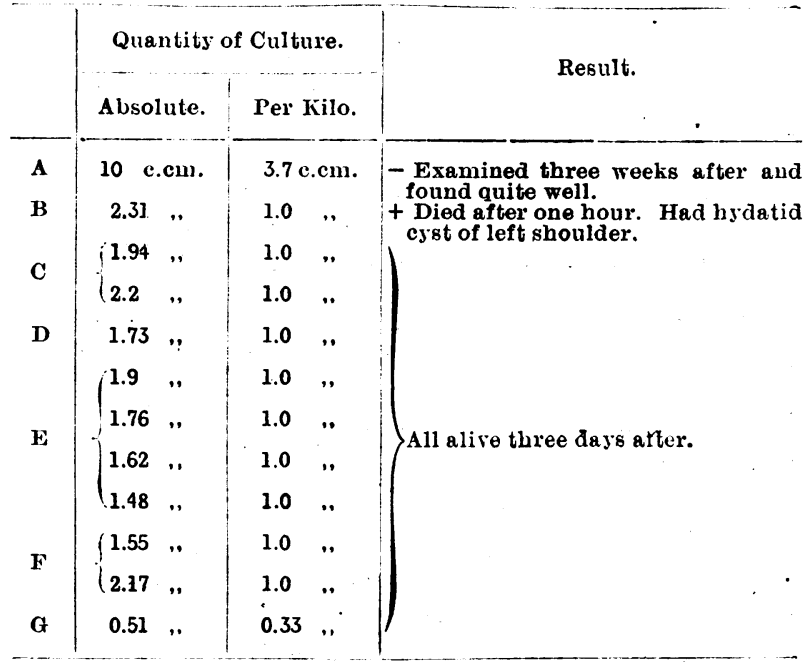

The above experiments were done with six different cholera cultures of twenty-four hours. In the case in which sudden death resulted the animal had hydatid disease. On the same day two other animals, marked $F$ in the table, were injected with the same amount of the same culture and were not affected by it. The brackets indicate batches injected from the same culture. From the above it is crident that $1.0 \mathrm{c.cm}$. per kilo of body weight is not fatal in a healthy animal.

The effect of the injection of eighteen to twenty-four hour cholera broth culture of the same strain in a large quantity of distilled water is illustrated in the following experiments :

18 to $2 \pm$ IIour Cultures.

\begin{tabular}{|c|c|c|c|}
\hline $\begin{array}{l}\text { Weight of } \\
\text { Animal } \\
\text { in Kilos. }\end{array}$ & $\begin{array}{c}\text { Quantity of } \\
\text { Culture } \\
\text { per Kilo. }\end{array}$ & $\begin{array}{c}\text { Distilled Water } \\
\text { Ratio to } \\
\text { Body Weight. }\end{array}$ & Result. \\
\hline$(151$ & 0.43 c.cm. & $x / 39$ & + immediaté. \\
\hline 1.91 & $0.17 \quad$ & $1 / 96$ & + \\
\hline$(1.50$ & $0.074 n$ & $x / 37$ & + \\
\hline $\int 1.57$ & 0.33 & $x / 30$ & - \\
\hline 1.82 & 0.066 & $1 / 30$ & + after 3 hours. \\
\hline 1.37 & 0.83 & $1 / 30$ & + after $1 \frac{1}{2}$ hours. \\
\hline 1.72 & 0.33 & $1 / 30$ & + after 4 minutes. \\
\hline 2.47 & 0.03 & $1 / 30$ & - \\
\hline
\end{tabular}

Similar results were obtained with other cholera cultures. It appears from the aljove that whilo all the cultures can produce acute death, some are more liable to give immediate death than others. We have not ascertained the cause of this irregularity.

\section{On the Separate Administration of Cholera Toxin and Distilled Water.}

In the first experiment cholera toxin of four days was injected into the peritoneum of two animals. Two hours afterwards water was injected intravenously in one of the animals as follows :

\begin{tabular}{|c|c|c|}
\hline Quantity of Toxin per Kilo. & Distilled Water. & Result. \\
\hline $1.0 \mathrm{c.cm}$. & $x / 78$ of body weight & + immediate. \\
\hline$-1.0 \ldots$ & None & - \\
\hline
\end{tabular}


In the second experiment water was injected intra icnously first. Cholera culture of eighteen hours' growth vas injected subsequently after varying intervals.

\begin{tabular}{|c|c|c|c|c|}
\hline \multicolumn{2}{|c|}{$\begin{array}{l}\text { Distilled } \\
\text { Water. }\end{array}$} & $\begin{array}{l}\text { Cholera } \\
\text { per Kilo. }\end{array}$ & $\begin{array}{l}\text { Interval of } \\
\text { Time. }\end{array}$ & Result. \\
\hline \multicolumn{2}{|c|}{$\begin{array}{l}1 / 30 \text { of body } \\
\text { weight }\end{array}$} & $0.33 \mathrm{c.cm}$. & 20 minutes & + after $2 \frac{1}{2}$ hours. \\
\hline , & , & $0.33 \quad "$ & 1 hour & $\begin{array}{l}\text { - very ill sloortly } \\
\text { after injection. }\end{array}$ \\
\hline ". & $"$ & $0.33 \ldots$ & $1 \mathrm{hr} .10 \mathrm{~min}$. & + next day. \\
\hline ", & $"$ & 0.33 & 2 hours & + next day. \\
\hline , & ", & $0.33 \quad$ & 18 hours & - \\
\hline
\end{tabular}

Administration of cholera toxin into the peritoneum and listilled - water in large quantity into the stomach occasioned no marked intoxication in the case of three animals.

In two pairs of animals an effort was made to prevent the acute intoxication produced by the injection of cholera culture in water by administering a concentrated salt solution intravenously inmediately before giving the toxin. The results were as follows:

\begin{tabular}{|c|c|c|c|c|}
\hline & $\begin{array}{l}5 \text { per Cent. } \\
\text { salt Solution. }\end{array}$ & $\begin{array}{l}\text { Cholera Cul- } \\
\text { ture per Kilo. }\end{array}$ & $\begin{array}{l}\text { Distilled } \\
\text { Water. }\end{array}$ & Result. \\
\hline 1. (1) & 20 c.cm. & 0.38 c.cm. & $\begin{array}{c}\text { y/43 of body } \\
\text { weight }\end{array}$ & + after 2 hours. \\
\hline (2) & None & $0.38 \quad "$ & " $\quad "$ & + immediate. \\
\hline 2. (1) & $20 \mathrm{c.cm}$. & $0.33 \quad$ " & $\begin{array}{l}\text { r/3o of body } \\
\text { weight }\end{array}$ & + after $3 \frac{1}{2}$ hours. \\
\hline (2) & None & $0.33 \quad$ " & " & + after 3 hours. \\
\hline
\end{tabular}

From which it appears that hypertonic saline does not hare a vel'y marked effect in preventing this intoxication.

In the cases of acute intoxication with diluted cholera toxin which we have been describing the animal show's paresis, which may commence in the fore or lind limbs, coma, convulsions with exophthalmos and opisthotonos.

The post-mortem findings are usually as follows: The portal system is congested, especially the small intestine. The peritoneum contains a little blood-stained fluid. The urine is blood-stained. The blood serum is tinted. The heart is usually filled with clot. The lungs are apparently normal on nalied-eye examination.

Experiments with Other Organisms.

A. Two experiments with Proteus vulgaris broth gave the following result:

1. Intrarenous Simultaneous Injection of Water and $2 \pm$ Hours' Culture.

\begin{tabular}{|c|c|c|c|}
\hline $\begin{array}{l}\text { Weisht of Rabbits } \\
\text { in Kilos. }\end{array}$ & $\begin{array}{l}\text { Culture per } \\
\text { Kilo. }\end{array}$ & Distilled Water. & Result. \\
\hline 1.60. & 0.33 c.cm. & $x / 30$ & + after hours. \\
\hline 2.06 & $0.033 \quad ":$ & $3 / 30$ & + after 2 hours \\
\hline 2.43 & 0.0033 & $1 / 30$ & + after 2 hours \\
\hline
\end{tabular}

Controls without Water.

\begin{tabular}{l|c|c|c|c}
2.14 & 2.0 c.cm. & None & - \\
1.35 & 0.33 & . & None
\end{tabular} \mid-

2. An Experiment in which the Culture (49 hours) was Injected Subcutancously into Two Animals and folloved in One' Animal by Distilled Water Intracenously.

\begin{tabular}{c|c|c|c}
$\begin{array}{c}\text { Yeight of Rabbits } \\
\text { in Kilos. }\end{array}$ & $\begin{array}{c}\text { Culture per } \\
\text { Kilo. }\end{array}$ & $\begin{array}{c}\text { Distilled Wa ter } \\
\text { Intravenously } \\
\text { after Interval of } \\
3 \frac{1}{2} \text { Hours. }\end{array}$ & Result. \\
\hline 3.01 & 2.5 & $\begin{array}{c}\text { I/r34 of body } \\
\text { weight } \\
\text { None }\end{array}$ & + after 4 min. \\
\hline 2.87 & 2.5 & -
\end{tabular}

B. B. pyocyaneus culture administered with and withont water gave the following result:

\begin{tabular}{|c|c|c|c|}
\hline $\begin{array}{l}\text { Weight of Rabbits } \\
\text { in Kilos. }\end{array}$ & $\begin{array}{l}\text { Culture per } \\
\text { Kilo. }\end{array}$ & Distilled Water. & Result. \\
\hline 2.29 & 0.33 c.cm. & r/3o of body weight & + after 2 hours \\
\hline 3.0 & $1.0 \quad$, & None & - \\
\hline
\end{tabular}

C. B. dysenteriae (Shiga) culture of twenty-four lo:u's administered with and without water.

\begin{tabular}{c|c|c|c}
\hline $\begin{array}{c}\text { Weight of Rabbits } \\
\text { in Kilos. }\end{array}$ & $\begin{array}{c}\text { Culture per } \\
\text { Kilo. }\end{array}$ & Distilled Water. & Result. \\
\hline 2.31 & 0.7 c.cm. & 1/300 b ody weight & + after 1! hour. \\
2.47 & 0.7 None & - & Non \\
\hline
\end{tabular}

D. B. prodigiosus culture gave similar results.

E. The bacillis of fowl cliolera is very fatal to rabbits, and usually lills in about twelve hours after intravenous injection, nevertheless the injection of distilled water in infected animals is liable to cause sudden death.

A rabbit of 2.45 kilos was given $0.33 \mathrm{c.cm}$. of a 24-lio:ur culture of the bacillus of fowl cholera per kilo into a vein of the ear, after 13 hours $20 \mathrm{c.cm}$. of distilled water were injected intravenously, when the rabbit died immediately.

F. Old tuberculin of Koch was given with and without water to the following animals.

\begin{tabular}{|c|c|c|c|c|}
\hline Quantity per Kilo. & \multicolumn{3}{|c|}{ Distilled Water. } & Result. \\
\hline ( $2.5 \mathrm{c.cm}$. & \multicolumn{3}{|c|}{ ri3o of the body weight } & + after 5 hours. \\
\hline $1.0 \mathrm{c.cm}$. & $I_{3}^{\prime} 30$ & $"$ & ", & - \\
\hline $0.1 \mathrm{c.cm}$ & 130 & ", & , & - \\
\hline 5.0 c.cul. & \multirow{2}{*}{\multicolumn{3}{|c|}{ None }} & - in transient convul- \\
\hline $2.5 \mathrm{c} \mathrm{cm}$. & & & & - no symptonis. \\
\hline
\end{tabular}

The toxic effect of tuberculin appears to be slightly increased by this method.

'The following experiments were done without acute death resulting, broth cultures of 24 hours being used in the case of each bacterium.

\begin{tabular}{|c|c|c|c|c|}
\hline & $\begin{array}{l}\text { Weight } \\
\text { in } \\
\text { Kilos. }\end{array}$ & $\begin{array}{c}\text { Quantity of } \\
\text { Culture } \\
\text { per Kilo. }\end{array}$ & $\begin{array}{c}\text { Distilled Water } \\
\text { Ratio to } \\
\text { Body Weight. }\end{array}$ & Resuit. \\
\hline \multirow[t]{2}{*}{ B. anthracis... } & 1.9 & $0.33 \mathrm{c} . \mathrm{cm}$ & $1 / 30$ & + on second \\
\hline & 1.74 & 0.33 & None & $\begin{array}{l}\text { day after. } \\
+ \text { on third }\end{array}$ \\
\hline \multirow[t]{2}{*}{ B. subtilis } & 2.06 & 0.33 & None & - dayarter. \\
\hline & 2.12 & $0.066 \quad \therefore$ & $1 / 30$ & - \\
\hline \multirow[t]{2}{*}{ Pneumococcus } & 2.23 & 0.33 & None & - \\
\hline & 2.32 & 0.066, & $x / 30$ & $-i:$ \\
\hline
\end{tabular}

Potassium Cyanide: Intravenous Administration.

One cubic centimetre per kilo of a 1 per cent. solution in distilled water of potassium cyanide was given to a rabbit of 1.37 kilos. The animal died at once. 1 c.cm. per kilo of a 0.1 per cent. solution was given to a second rabbit of 1.86 kilos. The animal was convulsed and lay for half an bour on its side unconscious, after which it.gradually recovered. A third rabbit of 1.77 kilos was given $1 \mathrm{c.cm}$. per kilo of the 0.1 per cent. solution of potassium cyanicle in one-thirtieth of the body weight of distilled water. The animal shorved no convulsions and was not unconscious, though it lay helpless and extended for ten minutes. Thic dilution appeared to have made the substance less toxic; 0.01 per cent. solution of the cyanide was then injected into two rabbits again, 1 c.cm. pel kilo being the amount used, but in the case of one of the rabbits it was added to one-thirtieth of the body weight of distilled water. No marked evidence of acute intoxication was found in cither animal.

Strychnine likewise suffered no argmentation of it: toxic action when given in distilled water. 
We attach little importance to the negative results with the bacteria above described, since exceptions occurred sometimes with the cholera experiments, and we may have been dealing with exceptions in these cases. We have not yet found a fully substantiated negative case in dealing with bacterial products.

Efforts at immunization against diluted cliolera toxin have not shown any striking results so far. Normal serum and ordinary anticholera serum when injected in advance are quite unable to prevent the acute intoxication resulting from diluted cholera culture or toxin when either of the lattcr is administered intravenously.

Cuuse of Augmentation of Toxicity.

The following experiments were done to investigate the cause of this augmentation of toxicity. Intravenous injections were used throughout.

1. One part of normal rabbit blood was lysed in two parts of distilled water and $10 \mathrm{c.cm}$. of the resulting mixture per kilo of body weight was given to two normal rabbits, in one case alone, in the second case with $1 \mathrm{c} . \mathrm{cm}$. per kilo of eighteen hours cholera broth. The latter animal died in two minutes, while the other animal is still alive; 1 c.cm. per kilo of eighteen hours cholera broth alone is a sublethal dose.

2. Rabbit blood was Jysed in twice its quantity of distilled water and $3 \mathrm{c.cm}$. per kilo of the mixture given to a furthe pair of normal rabbits, in the case of one animal alone, in the case of another animal with 1 c.cm. of eighteen hours choler culture per kilo. The former animal remained quite well, while the latter animal was very ill after one hour and in state of coma. It recovered, however, and appeared well the next day.

3. A further pair of animals were given lysed blood and lysed blood plus choler culture respectively the latter being in sublethal dose. The latter animal died, while the control with the lysed blood only, survived and did not appear ill.

These experiments suggested that lysis of the blood was an important factor in the augmentation of toxic action, but the injected fluid being of lower osmotic pressure than the blood, it was thought that the lysis of the blood might be effected with advantage by ether.

4. Lysis of the blood by ether was carried out, and after the cther was removed by means of a water pump the blood was administered as follows to normal rabbits:

\begin{tabular}{|c|c|c|c|c|}
\hline $\begin{array}{l}\text { Weight } \\
\text { of Animal } \\
\text { in Kilos. }\end{array}$ & $\begin{array}{c}\text { Ether 1rsed } \\
\text { Blood. }\end{array}$ & $\begin{array}{l}18 \text { Hours } \\
\text { Cholera } \\
\text { Culture. }\end{array}$ & Saline. & Result. \\
\hline 2.0 & 2.0 c.cinl. & None & None & - still surviving. \\
\hline 1.7 & $\begin{array}{l}1.7, " \\
1.9 \quad,\end{array}$ & $\begin{array}{l}1.7 \mathrm{c.cm} . \\
1.9\end{array}$ & $\begin{array}{l}56.6 \mathrm{c} . \mathrm{cm} . \\
\text { None }\end{array}$ & $\begin{array}{l}+ \text { during the night } \\
\text { unconscious in } 2 \\
\text { hours. } \\
+ \text { after } 2 \text { liours. }\end{array}$ \\
\hline
\end{tabular}

5. A further saniple of normal rabbit blood was lysed in ether and the ether removed as before described. It was then administered to normal rabbits as follows:

\begin{tabular}{|c|c|c|c|}
\hline $\begin{array}{l}\text { Weight in } \\
\text { Kilos. }\end{array}$ & $\begin{array}{l}\text { Fther lysed } \\
\text { Blood. }\end{array}$ & $\begin{array}{c}18 \text { Hours } \\
\text { Cholera Culture. }\end{array}$ & Result. \\
\hline 1.4 & 1.4 c.cm. & None & - still alire. \\
\hline 1.96 & 1.96, & None & - still alive. \\
\hline $1-93$ & 1.93, & $1.93 \mathrm{c.cm}$. & + after 2 hours. \\
\hline 2.26 & 2.26 & $2.26 \quad$, & $\begin{array}{l}+ \text { after } 2 \text { hours } \\
55 \text { minutes. }\end{array}$ \\
\hline
\end{tabular}

From these experiments we conclude that lysis of the blood is an important factor in the sensitization of the animal botly by water to bacterial poisons.

$6.15 \mathrm{c.cm}$. of rabbit blood were defibrinated and washed twice with saline solution. The volume of red cell emulsion left equalled $4.5 \mathrm{c.cm}$.; $13 \mathrm{c.cm}$. of distilled water were added to lyse the red cells. After lysis 0.11 gram of common salt was added to bring the added distilled water up to the strength of normal saline. The mixture was given, with and without cholera culture, to two animals as follows:

\begin{tabular}{c|c|c|c}
\hline $\begin{array}{c}\text { Weight of Rablbit } \\
\text { in Kilos. }\end{array}$ & $\begin{array}{c}\text { Lysed Blood } \\
\text { Nixture } \\
\text { (per Kilo). }\end{array}$ & $\begin{array}{c}\text { 18 Hours } \\
\text { Cholera Culture } \\
\text { (per Kilo). }\end{array}$ & Result. \\
\hline 1.70 & $4.0 \mathrm{c.cm}$. & $1.0 \mathrm{c.cm}$. & + within 3 hrs. \\
1.95 & None & -
\end{tabular}

This experiment was performed a second time and gave the same result. It appeared, therefore, that the lysis of the cellular elements of the blood as opposed to the effect of distilled water on the plasma was at least one cause of the augmentation of toxic action.

The following experiment supports this conclusion :

A rablit of 2.9 kilos had the following mixture injected intravenously : $4.35 \mathrm{c} . \mathrm{cm}$. of fresh rabbit serum was diluted with 97 c.cm. of distilled water (one-thirtieth of the body

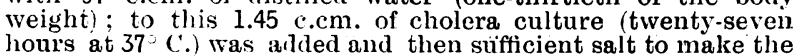
distilled water isotonic with the blood. The whole was injected intravenously; the animal survived.

At the same time an experiment was done which was identical with the above, except that the added distilled water was only equal to twice the volume of the serun. The animal which received this injection showed likewise no acute intoxication.

It appeared, therefore, that lysis of the blood was at least one factor in this augmentation of toxic action, and that the cellular elements of blood rather than the plasma or serum were the affected portions. To determine if this was due to lysis of the leucocytes, peritoneal exudate was then obtained from rabbit, and to it distilled water was added, followed by cholera culture (thirty-six hours), and sufficient salt to make the distilled water isotonic witl the blood; the mixture was then injected intravenously as follow: :

$$
\begin{aligned}
& \begin{array}{lllll}
\text { Weight of rabbit } & \ldots & \ldots & \ldots & 1.90 \text { kilos. } \\
\text { Exudate per kilo } & \ldots & \ldots & \ldots & 3.0 \mathrm{c.cm} .
\end{array} \\
& \text { Cholera culture per kilo } \ldots . . \quad \ldots . .1 .0,
\end{aligned}
$$

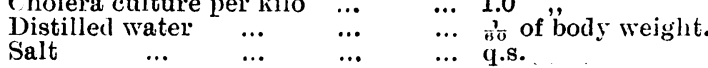

The animal survived, and showed no serious symptoms. This experiment was repeated and gave the same results. The experiments on the part played by the lysis of lencocytes in producing this effect are few, but suggest that it is an insignificant factor, while the lysis of red cells is of probably great importance.

\section{Conclusions.}

1. Distilled water sensitizes the body to many different bacterial cultures, including cholera culture.

2. The sensitization is equally well demonstrated by using cholera toxin after the actual organisms have becn entirely removed.

3. The intoxication with cholera toxin or culture in association with distilled water is acute, and death may be immediate.

4. Acute death occur's if the cholera culture or toxin be given first and the distilled water afterwards; the toxin may be given by channels other than the intravenous.

5. Previous injection of concentrated saline has little effect on the type of intoxication we have been discussing.

6. The augnentation of toxic effect occurs with cultures of Protelus vulgaris, B. pyocyaneus, B. dysenteriae (Shiga), $B$. prodigiosus, and also slightly with tuberculin, while it is not observed apparently with potassium cyanide or strychuine.

7. The injection of lysed blood in small doses with sublethal doses of cholera culture produces acute death.

8. The lysis of red cells is probably an important determining factor in the production of this effect.

${ }^{1}$ Hort and Penfold (1912), MEFERrences.

Micro-organisus and their Relation to Fever. Journal of Hygiene, vol. xii, p. 361. '2 Pottevin and Violle (i913), Sciences, p. 343.

Coloner WILLIAM C. GoRgas has been appointed by President Wilson to succeed the late General Torney as Surgeon-Geueral of the United States Army with the rank of Brigadier-General. Colonel Gorgas has been an offlcer of the American Arnv Medical Corps since 1885 and reached the rank of Colonel in March, 1913. His name is well known for the large part he played in the war against yellow ferer in Cuba, and especially for his splendid work in frecing the Isthmus of Panama from the demons of disease which had previously driven away the French. His appointment is said to be intended as a recognition of the rork done by him in the sanitation of the Panama Canal zone. He is, we believe, still in South Africa on his mission to advise on the means which may be taken to check pneumonia in the diamond mines, and generally as to the improrement of the sanitary conditions in those districts. 